\title{
The Effect of Introduction, Connection, Application, Reflection, and Extension (ICARE) towards Students' Chemistry Learning Outcome
}

\author{
Das Salirawati ${ }^{1 *}$, Erfan Priyambodo ${ }^{1}$, Metridewi Primastuti $^{1}$ \\ ${ }^{1}$ Department of Chemistry Department, Faculty of Mathematics and Sciences, Universitas Negeri Yogyakarta, \\ Indonesia \\ *Corresponding author. Email: das_salirawati@uny.ac.id
}

\begin{abstract}
This study aimed to analyze the differences in students' learning outcomes covered curiosity (SC), responsibility (SR) and cognitive achievement (SCA) between students subjected to ICARE model at the experimental class $(\mathrm{N}=68)$ and the control class without ICARE $(\mathrm{N}=69)$. This research is an experimental study using the posttestonly group design. The SC and SR were measured using a questionnaire that consisted of 20 statements outlined from 7 criteria using Likert scale. The questionnaire was validated theoretically $t$ by 3 expert judgments in the field of chemistry, education and evaluation to determine the appropriateness of the instruments. Therefore, SCA instrument was measured using 24 multiple choice questions that were validated empirically based on the ITEMAN program analysis. Research analysis results shows there were significant differences in students' learning outcomes between the experimental and control class. Based on the t-test results of each research variables, a significant value obtained was $<0.05$. Overall, this research has proved that the ICARE learning model has an effect on students' learning outcome, namely curiosity (SC) 13,6\%, responsibility (SR) 6,2\%, and cognitive achievement (SCA) $10 \%$. ICARE can be used as an alternative for teaching-learning activities, so that students can learn independently and expand their knowledge by finding out what they get from learning activities and being responsible for what they have understood.
\end{abstract}

Keywords: ICARE, Chemistry Education, Learning Outcome.

\section{INTRODUCTION}

The globalization era has an impact on all areas of life, including the field of education. Currently, there are many media, methods, and learning models being developed based on technological advances. One of them is learning by using other than books, for example e-learning, blended learning, and others. All subjects can be delivered using technology, including chemistry. Chemistry is one of the subjects that require a good mastery of concepts in solving problems [1]. Chemistry learning is not only memorizing concepts in students' brain memory, but must be accompanied by their real and scientific application in the learning process [2]. In learning, students need concepts to be mastered in their cognitive structures and at the same time apply direct experience as known as learning by doing so that learning process becomes meaningful [3]. In fact, the learning process that is taking place in schools at this time has not been able to create learning that supports the active role of students, such as curiosity about the topic and responsibility towards what they have been learned. Both of them become one of several factors of the benchmarks for the learning success of students at school that is cognitive achievement. If the curiosity and responsibility of students are good, then indirectly it will have an impact on good cognitive achievement as well. Unfortunately, students' curiosity and responsibility in Indonesia still need to improve. Based on the Organization for Economic Co-operation and Development 2018, the average score of students' scientific abilities is 389 out of 489. These results are not just a score but describe how the student's character behavior, learning conditions, and teacher teaching methods [4]. Therefore, extra effort is needed for improvement. One of the several ways is teaching strategy that chosen by teacher.

Why curiosity and responsibility become an important factor to foster students' cognitive achievement? Previous educational research, has been associated to curiosity. The interesting thing that 
curiosity measured as linked to the cognitive achievement and intelligence. Several research state that curiosity is more important than the intelligence because the confidence of students in what they have been know about the topic is important aspect to fostering their efficacy in the cognitive achievement [21]. Some observation suggest that curiosity may increase learning achievement because students need to thing about the gap between the new information and scientific material that they already know, linked to how to find the right answer and theories through the academic or scientific source. [22]. Besides, responsibility is one of the characteristics that students must have, especially when carrying out the tasks given by the teacher, because it is the obligation of a student [11][16]. This is because when students have responsibility, they will become disciplined in managing themselves to learn and getting the credible information. Thus, a decreased sense of responsibility will result in decreased awareness of the curiosity and moreover their achievement. Without any sense of responsibility in high level, students will not work optimally and tend to look for easy alternatives answer between the gap of new information and scientific knowledge, such as in doing tasks [23].

Fostering students' curiosity and responsibility also means an effort to improve student learning outcomes. One of the efforts that teachers can make is by choosing a learning model that is able to generate students' curiosity and responsibility. The Introduction Connection Application Reflection Extension (ICARE) learning model as a new learning model that teachers have not yet applied too many, today. This model was first applied by Bob Hoffman \& Donn Ritchie from the University of San Diego at 1998. ICARE is an information processing model in the form of digital modules. Students can access reviewed material that has been conveyed as outlined, and then deepen it through broadening the horizons and tasks that must be done. After completing one subject, the teacher can make the model ICARE which generally consists of five stages, namely Introduction (I), Connection (C), Application (A), Reflection (R), and Extension (E). At the Introduction stage (1), the teacher determines the content of the lesson to students, in this case it includes an explanation of the learning objectives, an outline of the activities, and what will be achieved during teaching and learning activities. Like the stages in teaching and learning activities in class, the connection stage (2) is known as apperception. The teacher presents the material to be delivered by connecting the previous material or phenomena in everyday life. Then, students begin to move on the application stage (3) after students acquire new knowledge and skills at the connection stage, students are given the opportunity to practice and apply their knowledge and skills at this stage the activity on the reflection stage (4) that invites students to ask themselves: do they understand the material being studied. At this stage, the teacher can invite students to make conclusions, such as question and answer activities or guide parts of the important material that have been studied sequentially. As a follow-up or expansion of the concepts that have been conveyed, teacher providing activities on the extension stage (5) that students can do after the lesson. The purpose of last stage is to strengthen and expand the material that students have learned. At this stage, the teacher can provide assignments or homework, and even look for additional learning references related to the material being studied [5]. In previous research [6] these stages made students curios and ask more critical questions to the teacher [7]. It is indicating students can play an active role in the teachinglearning process so that the topics that has been prepared on the ICARE learning model and digital module can be delivered and understanded [6].

Based on the background above, this research was conducted by applying ICARE and the results by analyzing the differences in students' learning outcomes covered curiosity, responsibility and cognitive achievement between students who are subject to the ICARE learning model and not, in the topic of electrolyte and non-electrolyte solutions. Electrolyte and nonelectrolyte solution topic were chosen because the previous research state that $60 \%$ students assumed the topic was difficult. They have a different conception about chemistry. It was evidenced through the cognitive test results below the minimum completeness criteria, students considered that electrons can flow on the aqueous solution without the ions through attracting of one ion to others [8][9].

\section{METHOD}

This research was quasi experimental using a posttest-only group design. The independent variable in this research was learning model, namely ICARE. There were three dependent variables that covered students' learning outcomes, namely curiosity, responsibility, and cognitive achievement on electrolyte and nonelectrolyte solution topic. Student grade $10^{\text {th }}$ on two public schools in Yogyakarta Province has been participated in this research. Students' in the experimental class $(\mathrm{N}=68)$ were subjected to the ICARE learning model, whereas students' in the control class $(\mathrm{N}=69)$ was learn about the same topic using the conventional teaching intervention, in three meetings include the post-test. The teaching intervention shown in Table 1. 
Table 1. Teaching intervention

\begin{tabular}{|c|c|c|}
\hline$y$ & ss & \\
\hline $\begin{array}{l}\text { Preliminary } \\
\text { Activity }\end{array}$ & $\begin{array}{l}\text { Teacher was asked to students about some } \\
\text { daily life phenomena that relate to the topic } \\
\text { of electrolyte and nonelectrolyte solution. At } \\
\text { this stage, teacher invite students' curiosity. }\end{array}$ & $\begin{array}{l}\text { Teacher determines the topic of the lesson } \\
\text { includes an explanation of the learning objectives, } \\
\text { an outline of the activities, and what will be } \\
\text { achieved during teaching and learning activities. }\end{array}$ \\
\hline $\begin{array}{l}\text { Core } \\
\text { Activity }\end{array}$ & $\begin{array}{l}\text { Introduction: teacher determines the topic } \\
\text { lessons including an explanation of the } \\
\text { learning objectives, an outline of the } \\
\text { activities, and what will be achieved during } \\
\text { teaching and learning activities. } \\
\text { Connection: teacher presents the topic } \\
\text { delivered by connecting the previous topic } \\
\text { and the phenomena in daily life. } \\
\text { Application: student try to answer the } \\
\text { phenomena given through the literature study } \\
\text { to acquire the new knowledge about the topic } \\
\text { that they've learn. } \\
\text { Reflection: students invited to ask } \\
\text { themselves about do they understand the } \\
\text { topic being studied, through the question- } \\
\text { and-answer activities. } \\
\text { Extension: teacher can provide assignments } \\
\text { or homework through the more complicated } \\
\text { phenomena that relate to the next topic. }\end{array}$ & $\begin{array}{l}\text { - The teacher provides the opportunity for } \\
\text { students to ask questions or find out about } \\
\text { relevant things that are in accordance with the } \\
\text { topic of discussion. } \\
\text { - The teacher providing initiation questions that } \\
\text { allow students to find scientific answers through } \\
\text { data collection or literature study by them self. } \\
\text { - The things that the students found related to the } \\
\text { topic being studied were confirmed by the } \\
\text { teacher through the presentation of the } \\
\text { electrolyte nonelectrolyte solutions topic. } \\
\text { - The teacher invites students to confirm the } \\
\text { concepts they have received through the } \\
\text { students' worksheet or assignments. }\end{array}$ \\
\hline $\begin{array}{l}\text { Closing } \\
\text { Activity }\end{array}$ & $\begin{array}{l}\text { Teacher invite students to make a conclusion } \\
\text { about the topic that they have been learned. } \\
\text { Moreover, teacher provide the conformation } \\
\text { and feedback towards students' conclusion. }\end{array}$ & $\begin{array}{l}\text { Teacher invite students to make a conclusion } \\
\text { about the topic that they have been learned. } \\
\text { Moreover, teacher provide the conformation } \\
\text { towards students' conclusion. }\end{array}$ \\
\hline
\end{tabular}

In this research, there are two questionnaire; students' curiosity (SC) and responsibility (SR). Each of the SC and SR consists of 20 statements outlined from 7 aspects referred to various sources and references, as shown in the Table 2 Besides, students' cognitive achievement (SCA) was measured using an instrument in the form of multiple-choice questions that consist of 30 items, each items had 5 options.
The questions focused on the topic of Electrolyte and Non-Electrolyte Solutions, that were has been empirically validated at non-sample classes. The results of the analysis using the ITEMAN program. The result obtained 24 valid questions and 6 invalid questions, but 24 valid questions still represented the sub-material in the Electrolyte and Non-Electrolyte Solution topic, as shown in Table 3.

Table 2. SC and SR Questionnaire

Curiosity Aspect

A. Finding out the new information

1,2

3 


\begin{tabular}{|c|c|c|c|c|}
\hline B. & Knowing something studied, seen, and heard, deeply. & 4,6 & 5,7 & 4 \\
\hline C. & Criticizing a new accepted information. & 8,10 & 9 & 3 \\
\hline D. & Finding more knowledge/information from various learning source. & 12,13 & 11 & 3 \\
\hline E. & Answer enthusiast. & 14,15 & 16 & 3 \\
\hline F. & Wondering the unclear knowledge/information to be understood. & 17,18 & - & 2 \\
\hline G. & Applying the new knowledge/information in everyday life & 19,20 & - & 2 \\
\hline & & & $\Sigma$ & 20 \\
\hline \multicolumn{5}{|c|}{ Responsibility Aspect } \\
\hline A. & Completing assignment on time. & 1,3 & 2 & 3 \\
\hline B. & Completing the task according to the instructions & 4,5 & 6,7 & 4 \\
\hline C. & Minimizing mistake & 8 & 9 & 2 \\
\hline D. & Fixing an error immediately & 10,11 & 12 & 3 \\
\hline E. & Taking the risk boldly & 13,15 & 14 & 3 \\
\hline $\mathrm{F}$. & Trying to complete the tasks individually & 16,17 & - & 2 \\
\hline G. & Studying hardly & 18,20 & 19 & 3 \\
\hline \multicolumn{4}{|r|}{$\Sigma$} & 20 \\
\hline
\end{tabular}

Table 3. Cognitive achievement instrument questions

\begin{tabular}{|c|c|c|c|c|c|c|c|}
\hline \multirow{2}{*}{ Sub-topics } & \multicolumn{6}{|c|}{ Cognitive Category } & \multirow{2}{*}{$\Sigma$} \\
\hline & C1 & $\mathrm{C} 2$ & C3 & C4 & C5 & C6 & \\
\hline $\begin{array}{l}\text { Definition of electrolyte non-electrolyte } \\
\text { solutions }\end{array}$ & 29 & $\begin{array}{l}1^{*}, 2,20 \\
28\end{array}$ & & & 19 & & 6 \\
\hline The electrolyte strength of the solution & 22 & & & $3,18,20$ & $12^{*}$ & 16 & 6 \\
\hline Electrical conductivity & & 6,9 & & $23,24,27$ & $26^{*}$ & & 6 \\
\hline Ionic compound & & 5 & & 4,14 & $13^{*}$ & & 4 \\
\hline Covalent-polar compound & & & & 21 & 10,15 & & 3 \\
\hline Ionization degree & & & $8^{*}$ & & $7,11^{*} 17,25$ & & 5 \\
\hline$\sum$ & & & & & & & 30 \\
\hline
\end{tabular}

*) incompatible to the validity criteria

Data of students' learning outcome was analyzed through the t-test to examine there was a difference between the two different treatments. The hypothesis prerequisite test was carried out first, namely in the form of a test of normality and homogeneity. After the data is declared normal and homogeneous, then the hypothesis was examined using independent $\mathrm{t}$ test.

\section{RESULTS AND DISCUSSIONS}

To answer the the research objective, data analysis that must be tested was the prerequisite hypothesis test in the form of normality test using Shapiro-Wilk and homogeneity test using Levene test on the SPSS
23 for windows. The results of prerequisite analysis shown in the Table 4.

Table 4. Pre-requisite analysis results

\begin{tabular}{|c|c|c|c|}
\hline & Experiment & Control & Homogenity \\
\hline \multicolumn{3}{|l|}{ Curiosity (SC) } & 0.461 \\
\hline $\mathrm{df}$ & 68 & 69 & \\
\hline Sig & 0.335 & 0.151 & \\
\hline Conclusion & \multicolumn{2}{|c|}{ Normal } & Homogen \\
\hline \multicolumn{3}{|c|}{ Responsibility (SR) } & 0.813 \\
\hline df & 68 & 69 & \\
\hline Sig & 0.241 & 0.481 & \\
\hline
\end{tabular}




\begin{tabular}{|c|c|c|c|}
\hline Conclusion & \multicolumn{2}{|c|}{ Normal } & Homogen \\
\hline \multicolumn{3}{|c|}{ Cognitive Achievement (SCA) } & 0.674 \\
\hline df & 68 & 69 & \\
\hline Sig & 0.198 & 0.060 & \\
\hline Conclusion & & mal & Homoger \\
\hline
\end{tabular}

The significant value of SC, SR, and SCA, both in the experimental and control classes greater than 0.05 . It is means that all of the data were normally distributed and homogeneous. Furthermore, the independent t-test can be continued. The test was carried out at a significance level of 0.05 . A summary of the t-test analysis results presented in the Table 5.

Table 5. Summary of t-test Analysis Results

\begin{tabular}{|r|l|l|l|}
\hline & SC & SR & SCA \\
\hline $\mathrm{t}$ & -4.616 & -2.988 & -3.868 \\
\hline $\mathrm{df}$ & 135 & 135 & 135 \\
\hline $\mathrm{Sig}$ & 0.000 & 0.003 & 0.000 \\
\cline { 2 - 4 } & Different & Different & Different \\
\hline $\begin{array}{r}\text { Partial } \\
\text { Eta }\end{array}$ & 0.136 & 0.062 & 0.100 \\
Square & & & \\
\hline
\end{tabular}

Table 5 shows the results of independent sample t-test analysis, both of all research variable obtained a significance value of $<0.05$ [19]. It is means that there are any differences in curiosity, responsibility, and cognitive achievement between students who are subject to the ICARE learning model and not, in the topic of electrolyte and non-electrolyte solutions.

\subsection{Differences in Curiosity (SC)}

The ICARE learning model displays many applications of the material studied in everyday life and provides assignments that require students to find their own answers through various learning sources. So that, students are given a task that is an extension of the material being studied, so they try to find out more deeply and broadly than just what is in the book or other credible source. Based on the t-test analysis, a significant value obtained was $0.00<0.05$ means that there is any difference in the curiosity between students who are exposed to learn using ICARE and not, whereas the effect of ICARE on students' curiosity was $13.6 \%$. If we look further from the percentage score of each curiosity aspects, can be seen the differences between two classes, as presented in the Figure 1.

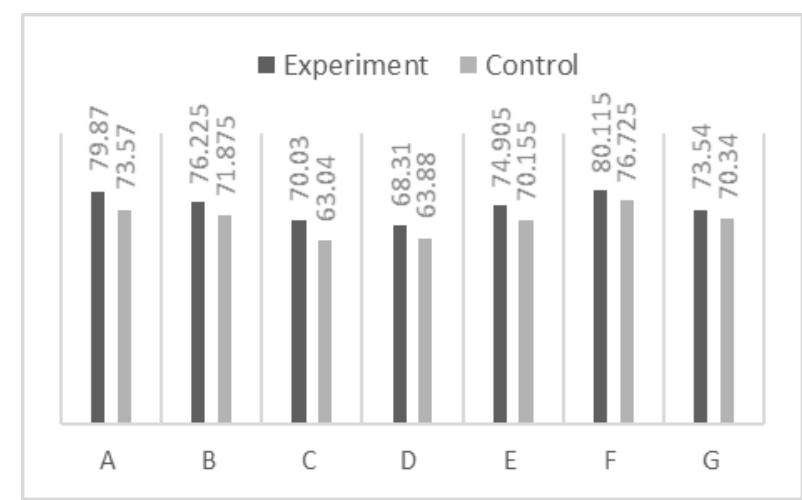

A. Finding out the new information

B. Knowing something studied, seen, and heard, deeply

C. Criticizing a new accepted information

D. Finding more knowledge/ information from various learning source

E. Answer enthusiast.

F. Wondering the unclear knowledge/ information to be understood

G. Applying the new knowledge/ information in everyday life

Figure 1. Percentage of each Curiosity Aspect

Figure 1 shows that the experimental class has a relatively higher percentage of the control class. The results of the data analysis of the SCI instrument showed that the two treatments gave relatively the same percentage results in terms of each aspect. Aspect $F$ (wondering the unclear knowledge/ information to be understood) gets the highest percentage, meaning that students in both classes have a high enough motivation (almost $80.115 \%$ ) to understand new or unclear information, followed by finding out new information (A-79.87\%), knowing something studied, seen, and heard, deeply (B$76.225 \%$ ), answering the questions enthusiast (E$74.905 \%$ ), applying the new knowledge/ information in everyday life (G-73,54\%), criticizing a new accepted information (C-70.03\%), and finding more knowledge/ information from various learning source (D-68.31\%).

In line with the theory presented in Graham's research [21] curiosity is important towards the intelligence because the confidence of students in what they have been know about the topic is important aspect to fostering their efficacy in the cognitive achievement. Students' curiosity (SC) that appears in learning activities is that students are encouraged to explore new information related to non-electrolyte electrolyte material. This is evidenced in learning activities, the process of seeking information by students is done by asking questions to the teacher when new information is conveyed in 
learning activities. These questions indicate the initiation of student curiosity and that students become more motivated to learn chemical concepts presented through phenomena in daily life. As mentioned in the results of the previous study [21] when students get new information, it will encourage students' motivation to find out the truth of the information obtained.

In accordance with the ICARE learning model which contains an invitation for students to know more about the material being studied, stimulate the emergence of students' critical attitudes towards the material being studied. It means, ICARE accommodate many applications of the topic studied in everyday life and provides assignments that require students to find their own answers through various learning sources. One of the characteristics of a critical attitude is a high curiosity about something for which the answer is unclear [11]. In addition, at the stage extension (follow-up), students are given a task that is an extension of the material being studied, so that they try to find out more deeply and broadly. The information and concepts presented in the ICARE digital learning module are presented as problems that need to be observed and analyzed by students, so that not all concepts are written in. Unfortunately, the solutions that students make prioritize the final answer more than the process. The weak ability of students in further analyzing learning topics has an effect on solving cognitive test questions. Through ICARE learning, students actually get the opportunity to find deeper information by looking for references about the information they just knew. This activity is a process significance which is expected as students' thoughts in presenting their understanding in teaching and learning activities. The activities of students who have curiosity can be observed by giving critical questions to the teacher. Furthermore, students can be more focused and careful on the topics being studied as the capabilities expected [12].

\subsection{Differences in Responsibility (SR)}

In this research, students' responsibility measured through the students' questionnaire analysis. Based on the results of t-test analysis, a significant value obtained was $0.003<0.05$ means that there is any difference in the responsibilities between students who are exposed to learn using ICARE and not, whereas the effect of ICARE on students' responsibility was $6.2 \%$. If we look further from the percentage score of each aspect, can be seen the differences between two classes, as presented in the Figure 2.

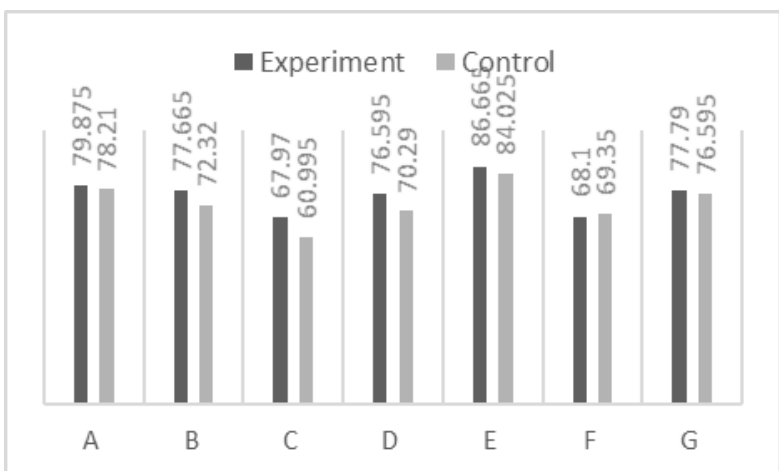

A. Completing an assignment

B. Completing the task according to the instructions

C. Minimizing the mistake

D. Fixing an error immediately

E. Taking the risk boldly

F. Trying to complete the tasks individually

G. Studying hardly

Figure 2. Percentage of each Responsibility Aspect Obtained

Figure 2 shows that the experimental class at has a relatively higher percentage than the control class. The results of the data analysis of the SR instrument showed that the two treatments gave relatively the same percentage results in terms of each aspect. Aspect E (taking the risk boldly) gets the highest percentage, followed by completing an assignment (A-79.875\%), studying hardly (G-77.79\%), completing the task according to the instructions (B77.665), fixing an error immediately (D-76.595), trying to complete the tasks individually (F-68.1\%), and minimizing the mistake (C-67.97\%).

Through the student responsibility questionnaire, it was found that the experimental class students were brave enough to take risks. The definition of risk in this questionnaire is that students have the courage to correct mistakes if the results of the teacher's assessment are not good. The improvement is done by doing the wrong answers to the assignments given by the teacher. This result is consistent with the acquisition of other aspects where students are serious about completing assignments on time and completing them independently as a form of responsibility for learning process. It is supported by the ICARE that requires students to repeat the material through the module packaging in the form of a digital module provided, so that at least the material can be understood better than students in the control class who are not asked to repeat. This is in line with the previous research (2013) which states that one of the characteristics of responsible students is that they will always complete the tasks assigned by the teacher, both at school and at home [13]. In other 
words, students in the experimental class when doing assignments or tests tend to try not to make mistakes.

One of the reasons why students feel bored with the assignments given by the teacher, and learning becomes unpleasant. Boredom reduces students' awareness of the importance of exercising their rights and obligations which are their responsibility and lack of confidence in their abilities. These two things greatly affect the low responsibility of students [14]. Responsibility is one of the characters that students must have, especially when carrying out the tasks given by the teacher, because it is the obligation of a student [15][20]. Thus, a decreased sense of responsibility will result in a decreased awareness of this obligation. Even though without a high sense of responsibility, students will not work optimally and tend to look for easy alternatives in doing assignments, for example by imitating the work of others.

\subsection{Differences in Cognitive Achievement (SCA)}

Based on the results of t-test statistical analysis, a significant value obtained was $0.00<0.05$ which means that there is a difference in cognitive achievement between students who are exposed to the ICARE learning model and not, whereas the effect of ICARE on SCA was 10\%. To measure SCA, some of the question items were contents of the application of electrolyte non-electrolyte solutions in everyday life, in line with the topic that has been prepared on the ICARE model learning media. Based on the descriptive analysis results, both of experimental and control classes gain the average score of 69 and 62 . Even though they were not complete the minimum completeness criteria, actually that may be caused by the online method that used in this research. So that, the effectiveness of learning model ICARE applied cannot be fully implemented well.

Table 6. Descriptive analysis results

\begin{tabular}{|c|c|c|}
\hline & Experiment & Control \\
\hline Mean & 68.60 & 62.03 \\
\hline Median & 66 & 62 \\
\hline Minimum & 50 & 41 \\
\hline Maximum & 95 & 87 \\
\hline Std. Error & 1.15 & 1.24 \\
\hline
\end{tabular}

However, ICARE trying to provides an opportunity to change students' learning experience through the integrated stage. In order to fostering students' cognitive achievement, ICARE as an integrated stage give a more valuable reality activity that relate to the concept that students learned at school. The concepts can be given as a problem that need to be solved by students, so that the learning activity more contextual.

In the application stage students acquire new knowledge and skills at the connection stage, students are given the opportunity to practice and apply their knowledge and skills about electrolyte and nonelectrolyte topic, as a reflection [16]. This activity was followed up on a post-test activity. The questions presented are the phenomenon of the non-electrolyte electrolyte concept in the daily life. Some of them are the phenomenon of charging cellphone batteries using lemons, students are invited to provide answers to facts that can be accounted for in terms of the concepts studied. Through questions like this, students are required to implement their curiosity in obtaining credible facts, so that the answers chosen can be accounted for. The problem that relates to the electrolyte nonelectrolyte in the everyday life phenomenon, was given with the hope that students can processing and analyzing what the information can be gained from the topic on the daily phenomena. Through that activity, students can build their understanding and improve their cognitive achievement [17].

As a research conducted before, advantages of the ICARE learning model that asks students to repeat the material through the module packaging in the form of a power point provided, so that at least the material can be understood better than students in the control class who are not asked to repeat. In this way, when they do assignments, there will be minimal mistakes made. In other words, students in the experimental class when doing assignments or tests tend to try not to make mistakes. In the ICARE learning model at the reflection stage which contains an invitation to link the material studied with the phenomena that occur around daily life, students feel led to answers to explanations of these phenomena. Likewise, in the extension stage where students are asked to work on assignments containing solving cases and collecting them at the next meeting, students try to complete the task as well as possible.

Unlike the transfer of knowledge, transfer of value or imparting character values is not an easy to do, it requires a long process and time. Therefore, habituation is needed, so that the values implanted can become values that are spontaneously carried out [18]. Even though character is difficult to instill in a short time, at least the application of the learning model ICARE in this study has been able to show differences in the curiosity and responsibility of students in the experimental class as indicated by the percentage of the seven criteria which is almost 
entirely higher than the students in the control class. From the descriptive analysis, students' responsibility was the highest gained with the average score of 75.55 followed by curiosity 71.76. Unfortunately, students' cognitive achievement gained the score of 65.29 and still not reached the minimum completeness criteria. Regardless of the limitations of this study, overall, this research has proved that the ICARE learning model has an effect on students' learning outcome, namely curiosity (SC) 13,6\%, responsibility (SR) 6,2\%, and cognitive achievement (SCA) $10 \%$ at the electrolytes-nonelectrolyte topic.

\section{CONCLUSION}

This study was conducted to analyze the effect of the I-CARE implementation towards students' learning outcomes. Based on the t-test results and research discussion, it can be concluded that there are any differences in curiosity, responsibility, and cognitive achievement between students who are subjected to learn about electrolyte nonelectrolyte solution using ICARE and not. Although the influence of ICARE on each variable is below $20 \%$, it is hoped that the results of the study can be continued to develop/implementing ICARE on the teachinglearning activity es such as to examine students' motivation in terms of their curiosity or efficacy. Through that way, students can learn the chemistry topic independently. And they can expand their knowledge by finding out what they get from learning activities and being responsible for what they have understood.

\section{AUTHORS' CONTRIBUTIONS}

Dr. Das Salirawati, M.Si conceived and planned research implementation and preparation of the instruments, besides Erfan Priyambodo, M.Si and Metridewi Primastuti, M.Pd collecting the research data. All of authors contributed to provide feedback and helped the results of research analysis to the interpretation and final manuscript.

\section{ACKNOWLEDGEMENT}

The authors enormously grateful to Faculty of Mathematics and Sciences (FMIPA), Universitas Negeri Yogyakarta for funding this research through Research Group of 2020.

\section{REFERENCES}

[1] S. Maya, Mulyani \& Saputro. 2017. Application of the POE Learning Model with the Practicum Method to Increase Curiosity and Achievement in High School Chemistry Learning. J. of Educ. Res, 20(1).

[2] Haryadi, Deni \& S. Nurhayati. 2015. Application of theModel Learning Start with theApproach ICARE to Learning Outcomes. J. of Chem. Educ \& Innovation, 9 (2).

[3] Hernawan, A. Herry., Asra \& D Laksmi. 2017. Elementary Learning and Learning. Bandung: UPI Press.

[4] Organization for Economic Co-operation and Development. 2019. PISA 2018 Results (Volume I): What Students Know and Can Do. OECD.

[5] L Triani. 2018. Learning ICARE Practicum Assisted: Improving Problem Solving Skills and Student Learning Outcomes on Animal Network Materials. J. of Sci. Educ. \& Innovation, 4 (2).

[6] B. Hoffman \& D. Ritchie. 1998. Teaching and Learning Online: Tools, Templates, and Training, SITE Annual 1998, (Society for Information Technology and Teacher Education, CD-ROM edition, Assoc. for the Advancement of Computing in Education, Charlottesville, VA.

[7] N. K. D. Ardiyani, I G. M Darmawiguna \& I. G. P. Sindu. 2017. Application of the Learning Model ICARE to Improve Learning Outcomes of Digital Image Processing. KARMAPATI, 6(3).

[8] M. Samani. 2013. Character Education. Bandung: Youth Rosdakarya

[9] D. K. Sari, Muchlis, \& R Hidayah. 2018. Implementation of basic brainsorming based on learning cycle $5 \mathrm{E}$ model to complete student learning outcome of X-Science students on the material of electrolyte and nonelectrolyte solution in SMAN 1 Sidoarjo. UNNESA Journal of Chemical Education, 7(34).

[10] T Hadinugrahaningsih, R. E.. Andina, L. R. Munggaran, \& Y. Rahmawati, 2020. Analysis of students' alternative conceptions about electrolyte and nonelectrolyte solutions using a two-tier diagnostic test for chemistry teaching improvement. Universal J. of Educ. Res., 8(5).

[11] H. Widyaningtyas, R. Winarni \& $\mathrm{T}$. Murwaningsih. 2018. Developing Students Responsiveness Through Numbered Head Together Model in Social Science Learning at Elementary Learning. Int. J. of Indonesian Education and Teaching. Vol. 2 (2)

[12] Scriven, M., \& Paul, R. (2016). Defining Critical Thinking: A Draft Statement for the National Council for Excellence in Critical Thinking. 
criticalthinking.org/University/univlibrary/librar y.nclk.

[13] Snuraya J, Wahyuni I, Panggabean DD \& Tarigan R (2019) Optimize use of icare based student worksheet (ICARE-BSW) in physics learning at the introduction level Journal of Physics: Conference Series 13170120161 1-12 doi.org/10.1088/1742-6596/1317/1/012161

[14] P. Wulandari Afsari. 2013. Implementation of Positive Reward Technique Behavioral Counseling to Increase Academic Responsibility for Class-X Students of Academic Year 2012/2013. Undiksha, 2(1).

[15] Syafitri. 2017. Increasing Learning Responsibilities ThroughStrategies Giving Questions and Getting Answers to Students. Journal of Educational Research and Development, 1(2).

[16] E. R. Wati. 2017. Application of STAD Type Cooperative Learning Model to Improve Discipline Character and Responsibilities and Science Learning Outcomes in Class IV Students. Educational Partners E-Journal, 1 (6).

[17] Y. N. Asri, D. Rusdiana \& S Feranie. 2016. ICARE model integrated with science magic to improvement of students' cognitive competence in heat and temperature subject. International Conference of Mathematcs and Science Education, vol.57.

[18] M Suendarti \& H Liberna. 2018. The effect of ICARE learning model on the students' metacognition Journal of Mathematics Education, 3(2)

[19] P. Suparno. 2002. Character Education in Schools, An Overview. Yogyakarta: Kanisius.

[20] J. Pallant. 2007. Manual survival SPSS. Australia: Open University Press.

[21] P. Graham. \& J. Helen. 2011. Stimulating curiosity to enhance learning. Education Science and Psychology, Vol 2(19).

[22] J.D. Coie. An evaluation of the cross situational stability of childern's curiosity. Journal of Personality, Vol 42.

[23] K. M. Arista. 2018. Penerapan model pembelajaran problem-based learning untuk meningkatkan tanggung jawab dan hasil belajar siswa. Jurnal Kajian Penelitian Pendidikan dan Pembelajaran, Vol 2(2). 